\title{
TOXIC EFFECTS OF POLYCYCLIC AROMATIC HYDROCARBONS IN A WATER MEDIUM FROM DIESEL COMBUSTION
}

\author{
L.A.D.KOSLOWSKI ${ }^{3}$, S.H.W. MEDEIROS ${ }^{1}$, T.M.N OLIVEIRA ${ }^{2}$, C.E. GALOSKI ${ }^{2}$, R.A.

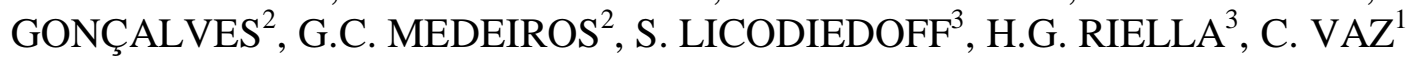 \\ ${ }^{1}$ Universidade da Região de Joinville - Univille, Departamento de Engenharia Química \\ ${ }^{2}$ Universidade da Região de Joinville - Univille, Departamento de Engenharia Ambiental \\ ${ }^{3}$ Universidade Federal de Santa Catarina - Departamento de Engenharia Química e de Alimentos \\ E-mail: lucianoandre @yahoo.com
}

\begin{abstract}
Most energy consumed on the planet derives from petroleum, coal and natural gas and the air pollution caused by such combustion is largely solved in water resources. The reaction produces highly toxic polycyclic aromatic hydrocarbons (PAHs). Current analysis evaluates the toxic effects of gas emissions from the combustion of diesel S10, S50 and B2 in a stationary engine. Methodology comprises the absorption of combustion gases in de-ionized water, with a fixed bed column. Absorption water is used for acute toxicity assays on Mysidopsis juniae, following norms by ABNT 15308. PAHs are quantified by fluorometry. Results showed an average concentration of $34.65 \mathrm{mg} . \mathrm{L}^{-1}$ of total PAH in the collected water sample. A $100 \%$ mortality of Mysidacea occurred in all dilutions in the three toxicity assays, except control, with a survival rate of $100 \%$ in both cases.
\end{abstract}

\section{INTRODUCTION}

Most energy produced and consumed comes from petroleum, coal and natural gas. Since these sources are limited and exhaustion forecasts have already been made, the search for alternative sources is highly relevant. Biodiesel seems to be an alternative to replace diesel oil in compression ignition engines already employed in several countries (Ferrari, Oliveira et al., 2005).

Biodiesel is generally defined as the monoalkyl ester derivative of long chain fatty acids from renewal sources, such as vegetal oils or animal fat, whose association is linked to the substitution of fossil fuel in compression ignition engines (Diesel engines) (Costa Neto, Rossi et al., 2000).

Brazil is a country with high agronomic advantages due to its tropical conditions, high luminosity rates and yearly mean temperatures. Further, water availability and regular rainfall make the country one of the greatest potential producers of renewable energy on the planet.

In the specific case of biodiesel, Brazil and Germany (Paulillo, Vian et al., 2007) are leaders in 


\section{9 a 22 de outubro de 2014 \\ Florianópolis/SC}

world consumption, with a Brazilian demand of 2.8 billion liters against a German counterpart of 2.6 billion liters in 2011. Brazil and Germany have specific laws to stimulate a 5\% biodiesel replacement for petroleum (ANP, 2011).

Diesel-powered vehicles are actually the greatest source of air pollution. In fact, the fuel causes global warming through gas discharges such as $\mathrm{CO}_{2}$ in motorized vehicles. Since people are exposed to this air pollution at all instances, several lung diseases are a consequence of particle emitting, such as dust, soot and smoke, caused by diesel-run motors. On the other hand, biodiesel is a non-toxic and biodegradable fuel. When compared to diesel oil, biodiesel does not produce sulfur and emits less carbon dioxide and carbon monoxide and more oxygen. A great amount of free oxygen produces complete combustion and reduced emissions. Since total biodiesel emission rates are comparatively less than diesel emissions, the alternative is highly promising for a less polluted environment (Chincholkar, Srivastava et al., 2005). Studies on toxicity and diesel oil combustion emissions are normally linked to their direct impact, caused by air pollution, on human beings, especially with regard to the respiratory system (Bünger, Krahl et al., 1998; Tsukue, Okumura et al., 2010). Further, only scanty information exists on the impact of these emissions on water bodies. In fact, the latter are the final destination of any type of air pollution, due to solubility in rain water or to direct solubility on the water surface by diffusion or convection processes.

Ocean water has been significantly affected by anthropogenic activities, especially and significantly by the combustion of fossil fuel. Global warming and ocean water acidification are directly related to $\mathrm{CO}_{2}$ emissions and by other gases in the earth's atmosphere. Effects range from the reproduction difficulties in some species to the excessive decrease of others, such as coral reefs, due to changes in water temperature and $\mathrm{pH}$ (Halpern, Walbridge et al., 2008).

Current research evaluates PAHs by gas emission in an absorption column derived from the combustion of diesel B2, diesel S10 and diesel S50 and performs toxicity tests with Mysidacea during 96 hours, following ABNT norm 15308.

\section{MATERIALS AND METHODS}

Current chapter includes the materials and methods that define the stages to comply with the aims proposed.

\subsection{Materials}

Diesel (B2, S10 and S50) samples were acquired from Petrobras petrol stations in the whereabouts of São Bento do Sul SC Brazil, so that variations in fuel type would be avoided.

Experiments were undertaken with a fixed base absorption column, as shown in Figure 1. 


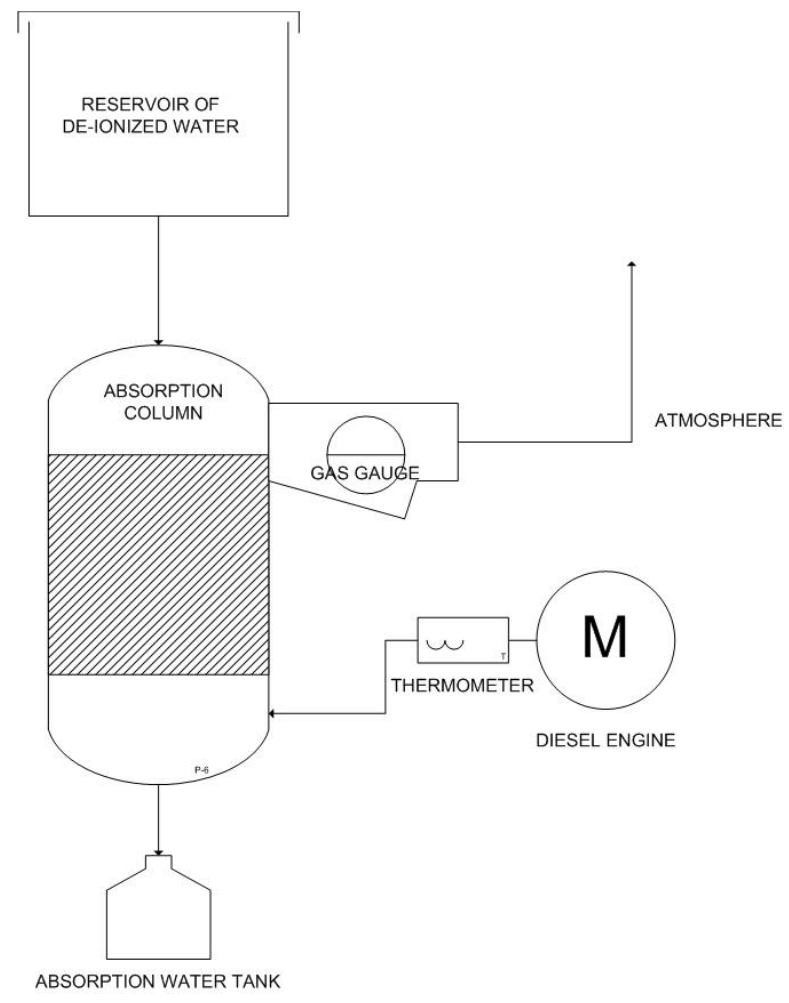

Figure 1 - Cross-section of gas absorption system.

Fixed based absorption columns are the most used process for gas de-pollution where chemical removal of pollutants occurs by absorption (Couvert, Sanchez et al., 2008). Although mass transference in the process is more intense than that in natural processes, the methodology is needed to concentrate the emission in water till saturation and thus establish dilutions for toxicity tests and the quantification of solute material.

The stainless steel column, resistant to brine, avoided the contamination of water by materials other than the fumes emitted from the stationed motor's exhaustion pipe. China fragments were used as fillings.

PAHs Enviroflu gauge TRIOS Optical Sensors was employed to quantify total PAHs in water (Figure 2). 


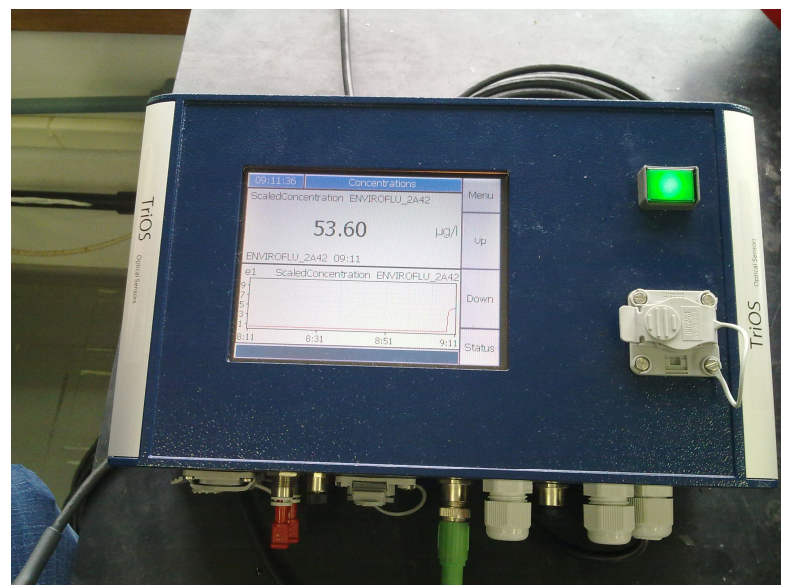

Figure 2 - Apparatus to quantify HPA in water

Digital pHmeter, available at the Environment and Ecotoxicology Laboratory, was employed to measure $\mathrm{pH}$, to identify the intensity of $\mathrm{pH}$ alteration due to the water acidification process by combustion gases, some of which are precursors of acid formation in the water medium.

\subsection{Methodology}

Water used in the column for gas solubilization to perform tests with Mysidopsis juniae was obtained by de-ionization. The method avoided interferences from ions with regard to results of acute toxicity assays.

Absorption column functioned in countercurrent, with an ascending flow of gases from the exhaust pipe and a descending water flow in the column. After the passage of water and gases through the column, the processed water samples were stored in borosilicate glass flasks and kept at $2-4{ }^{\circ} \mathrm{C}$ for a maximum period of 4 hours till the start of the tests to maintain the initial characteristics after the absorption process.

After the combustion gases were solved in water, samples were prepared for toxicity assay with different concentrations to identify CL50 (median lethal concentration), or rather, the concentration in which $50 \%$ of the population exposed to the organisms die. Tests with Mysidacea lasted 96 hours, following ABNT norm 15308 (ABNT, 2011), employed in the Environmental Toxicological Laboratory of the Universidade da Região de Joinville (Univille), campus São Francisco do Sul SC Brazil

The concentrations $0.1 \%, 0.25 \%, 0.5 \%, 1 \%, 2 \%$ and $10 \%$ of water from the absorption process were defined for the test. Toxicity tests were performed at $25{ }^{\circ} \mathrm{C}$, photoperiod $12 \mathrm{~h} / 12 \mathrm{~h}$ light/dark and feed for organisms consisted of nauplia of Artemia sp. enriched with fish oil and Omega 3. Organic compounds are known to have a higher volatilization in salty water (Schwarzenbach, Gschwend et al., 2005). Consequently, samples were placed in flasks with lid and separated in an incubator different from those with the negative control. 


\section{RESULTS AND DISCUSSION}

Table 1 shows results of PAHs and $\mathrm{pH}$ measurements of the samples collected in the absorption column as a result of the absorption in water of gases from the combustion of diesel B2, diesel S10 and diesel S50.

Table 1 - Data of PAHs concentration $\left(\mu \mathrm{g} . \mathrm{L}^{-1}\right)$ and $\mathrm{pH}$ derived from combustion of diesel B2, diesel S10 and diesel S50 in water.

\begin{tabular}{|c|c|c|c|c|c|c|}
\hline Time (min) & $\begin{array}{c}\text { Diesel B2 } \\
\text { PAHs }\left(\mu \mathrm{g} . \mathrm{L}^{-1}\right)\end{array}$ & $\begin{array}{c}\text { Diesel B2 } \\
\mathrm{pH}\end{array}$ & $\begin{array}{c}\text { Diesel S10 } \\
\text { PAHs }\left(\mu \mathrm{g} . \mathrm{L}^{-1}\right)\end{array}$ & $\begin{array}{c}\text { Diesel S10 } \\
\mathrm{pH}\end{array}$ & $\begin{array}{c}\text { Diesel S50 } \\
\text { PAHs }\left(\mu \mathrm{g} . \mathrm{L}^{-1}\right)\end{array}$ & $\begin{array}{c}\text { Diesel S50 } \\
\mathrm{pH}\end{array}$ \\
\hline $1 \mathrm{~min}$ & 60.21 & 3.60 & 47.20 & 3.63 & 36.35 & 3.80 \\
\hline $5 \mathrm{~min}$ & 47.50 & 3.40 & 38.40 & 3.50 & 36.25 & 3.65 \\
\hline $10 \mathrm{~min}$ & 44.85 & 3.30 & 32.20 & 3.43 & 34.47 & 3.55 \\
\hline $15 \mathrm{~min}$ & 38.24 & 3.15 & 27.62 & 3.37 & 32.26 & 3.52 \\
\hline $20 \mathrm{~min}$ & 34.75 & 3.11 & 26.15 & 3.30 & 30.40 & 3.45 \\
\hline $25 \mathrm{~min}$ & 33.64 & 3.10 & 25.80 & 3.29 & 29.50 & 3.43 \\
\hline
\end{tabular}

Table 1 shows that $\mathrm{pH}$ of solubilized water with gases from the combustion of diesel B2 had a low $\mathrm{pH}$ rate (3.10) when compared with the pH of diesel S10 (3.29) and diesel S50 (3.43). Decrease of $\mathrm{pH}$ of solubilized water with gases from combustion may be attributed to sulfur ( $50 \mathrm{ppm}$ of sulfur in diesel S50 and $10 \mathrm{ppm}$ of sulfur in diesel S10). The formation of gas products in combustion (CO, $\mathrm{CO}_{2}, \mathrm{NO}_{2}, \mathrm{NO}_{\mathrm{x}}, \mathrm{SO}_{2}$ and $\mathrm{SO}_{\mathrm{x}}$ ) significantly contributes towards water acidification, as Table 1 shows.

Data in Table 1 and Figure 3 show that the variation in the concentration of total PAHs due to diesel combustion time may be the result of several types of PAHs structures. The PAHs of small molecular mass may be volatilized from water of natural systems as the half-life of the volatilization of naphthalene between 0.4 and $3.2 \mathrm{~h}$ and anthracene in $17 \mathrm{~h}$ indicate (Southworth, 1979). However, PAHs with high molecular weight, such as pyrene, had a half-life of volatilization of 3.2 years (Southworth, 1979). High molecular weight PAHs comprise some of the most cancer-producing compounds known due to the production of different types of tumors. Substitutions in PAHs molecules increase toxic capacity (CEPA, 1996). 


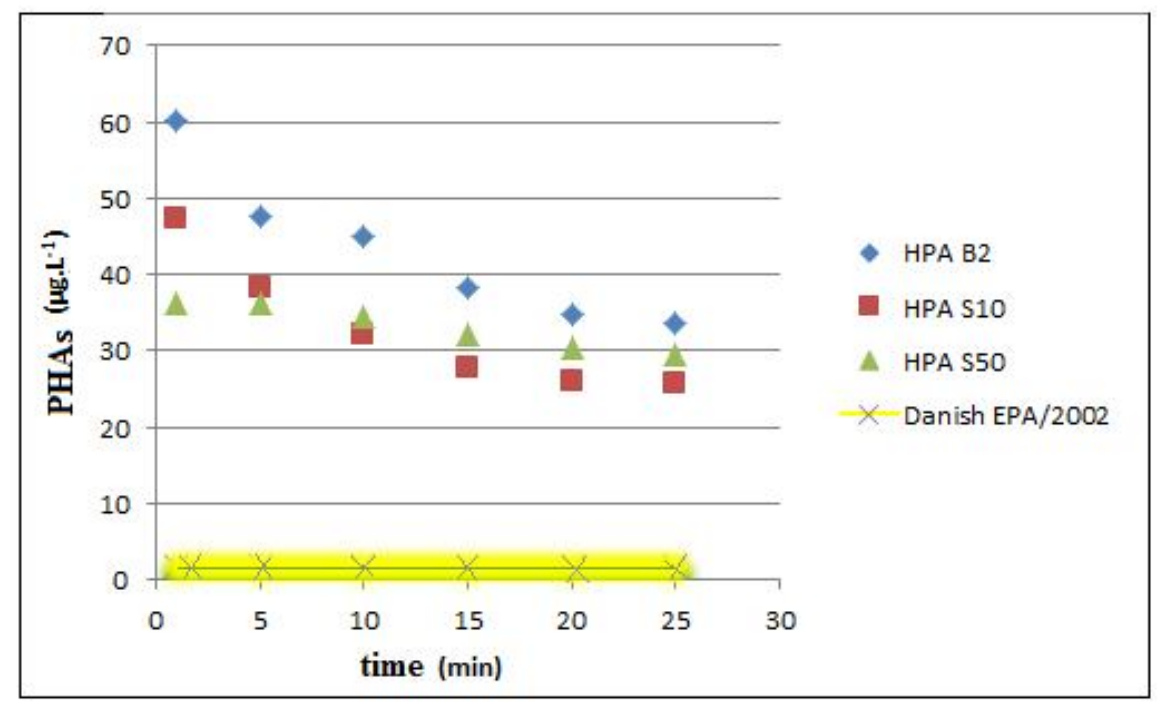

Figure 3 - Data from PAHs of diesel B2, diesel S10 and diesel S50 combustion at different sampling times.

PAHs are listed as dangerous compounds in the laws of some countries although there is no strict standard quality for the molecules. Benzo[a]pyrene is reported carcinogenic with considerable evidence in animals but slight ones in humans. The Occupational Safety and Health Administration (OSHA) established a $0.2 \mu \mathrm{g} / \mathrm{L}$ limit of PAHs for possible effects to human health (Naqia, 1999). Figure 3 shows PAHs concentrations from the emissions of diesel B2, diesel S10 and diesel S50 are above those established by Danish EPA/2002 which establishes $0.50 \mu \mathrm{g} / \mathrm{L}$ as emission limit for benzo[a]pyrene. Rates in current study $(33.64 \mu \mathrm{g} / \mathrm{L}$ for diesel B2; $25.90 \mu \mathrm{g} / \mathrm{L}$ for diesel S10 and 29.50 for diesel S50) reveal a mean concentration 60 times higher than the rate limit of the emission permitted by the norm. It should be underscored that HPAs concentration of current study refers to total concentration of PAHs, whereas Danish EPA/2002 uses benzo[a]pyrene as reference.

Rest results were evaluated within working conditions of the stationary engine for combustion of diesel B2, diesel S10 and diesel S50. A possible explication for the higher emission of diesel B2 when compared to that of diesel S10 and diesel S50 may be the use of a mixture of biodiesel to the diesel in diesel engines which are not adapted to complete combustion with mixtures. The working of engines of the diesel cycle is directly related to the manner the fuel is injected in the combustion chamber and burnt. Compression rate is incomplete, with an increase in PAHs emission.

In the case of the PAHs emission of diesel S10 and diesel S50, a possible explication may be due to the fact that the hexadecane index (NC) of diesel S 50 is lower than that of Diesel S10. Although it is similar to the octane scale used for petrol, the NC scale describes the ignition quality of diesel and its compounds. A higher NC (Diesel S10) provides a more efficient mix relationship between fuel and air for lower combustion and temperatures, according to data in the assays. Cordeiro (2003) shows the predominance of pyrogenic-derived PAHs when compared to fossil sources. The 


\section{9 a 22 de outubro de 2014 \\ Florianópolis/SC}

study established that approximately $89 \%$ of PAHs have high molecular weight, whereas the other $11 \%$ have a low one (Cordeiro, 2003). Pyrogenic PAHs are predominantly generated by atmospheric emissions, by combustion engines, burning of garbage, fires and several burning objects. Pollution of petrogenic origin is provided by spills, overflows and industrial, commercial and domestic handling of petrochemicals and by leaching of oils, fats and fuels.

Since results of the toxicity assays caused $100 \%$ mortality of the microorganisms in all dilutions with the water sample with PAHs, high toxicity of the solubilized compounds has been demonstrated. Further assays with lower concentrations will be performed so that the CL50 for Mysidacea may be found and the toxicity between the different fuels employed may be compared. Negative control (from the same culture water) did not cause any death during 96 hours.

\section{CONCLUSION}

The fixed bed absorption column system was adequate for the process under analysis since samples of water with PAHs concentration at $36.25 \mu \mathrm{g} . \mathrm{L}^{-1}$ were obtained. Toxicity assays with Mysidaceae showed that samples had high toxicity since mortality of all organisms occurred after 96 hours in $0.1 \%$ dilutions of the sample. Results suggest that further assays should be performed to validate PAHs quantifications and discover the LC50 of Mysidaceae so that the fuel with the lowest impact on marine environment could be evaluated.

\section{REFERENCES}

ASSOCIAÇÃO BRASILEIRA DE NORMAS TÉCNICAS. Resíduos sólidos - Classificação: NBR 10.004/04. Rio de Janeiro, 2004.

ANP. Produção Nacional de Biodiesel Puro - B100 (barris equivalentes de petróleo). Brasília, 2011.Disponívelem:http://www.google.com.br/url?sa=t\&rct=j\&q=anp\%20produ\%C3\%A7\%C3\%A3 o\%20de\%20biodiese1\%20no\%20brasil\&source=web\&cd=1\&ved=0CC0QFjAA\&url=http $\% 3 \mathrm{~A} \% 2 \mathrm{~F}$ \%2Fwww.anp.gov.br\%2F\%3Fdw\%3D8739\&ei=2KVMUJqXBYik8QTN9oCABw\&usg=AFQjCNF CyMy1T7o713UMJ_dtkPK2PSJmpA >. Acess in: 09/04/2014.

BÜNGER, J. et al. Mutagenic and cytotoxic effects of exhaust particulate matter of biodiesel compared to fossil diesel fuel. Mutation Research/Genetic Toxicology and Environmental Mutagenesis, v. 415, n. 1-2, p. 13-23, 1998.

CEPA. Canadian Environmental Protection Act. Polycyclic Aromatic Hydrocarbons. Priority Substances List. Assessment Report Government of Canada Environment Canada. National Printers (OTTAWA) Inc. 69 p., 1996.

CHINCHOLKAR, S. P. et al. Biodiesel as an Alternative Fuel for Pollution Control in Diesel Engine. Asian Journal of Experimental Sciences, v. 19, n. 2, p. 13-22, 2005. 
CORDEIRO, L.H., HIDROCARBONETOS POLICÍCLICOS AROMÁTICOS NOS SEDIMENTOS DO ESTUÁRIO DA LAGUNA DOS PATOS - RS. Dissertação de Mestrado, UFRG, 2003.

COSTA NETO, P. R. et al. Produção de biocombustível alternativo ao óleo diesel através da transesterificação de óleo de soja usado em frituras. Química Nova, v. 23, p. 531-537, 2000.

COUVERT, A. et al. Scrubbing intensification for sulphur and ammonia compounds removal. Chemosphere, v. 70, n. 8, p. 1510-1517, 2008.

DANISH ENVIRONMENTAL PROTECTION AGENCY. Environmental Guidelines Nr.1 2002 Vejledning fra Miljostyrelsen. Guidelines for air Emission regulation: Limitation of air pollution from installations, p.38, 2003.

FERRARI, R. A.; OLIVEIRA, V. D. S.; SCABIO, A. Biodiesel de soja: taxa de conversão em ésteres etílicos, caracterização físico-química e consumo em gerador de energia. Química Nova, v. 28, p. 1923, 2005.

HALPERN, B. S.; WALBRIDGE, S.; SELKOE, K. A.; KAPPEL, C. V.; MICHELI, F.; D'AGROSA, C.; BRUNO, J. F.; CASEY, K. S.; EBERT, C.; FOX, H. E.; FUJITA, R.; HEINEMANN, D.; LENIHAN, H. S.; MADIN, E. M. P.; PERRY, M. T.; SELIG, E. R.; SPALDING, M.; STENECK, R.; WATSON, R. A Global Map of Human Impact on Marine Ecosystems. Science. Issue 5865, v.319, p.948-952, 2008.

NAQIA. National Air Quality Information Archive. United Kigdom, 1998.

OSHA. Occupational Safety \& Health Administration: The Osha Rulemaking Process, 2013. Disponível em: https://www.osha.gov/law-regs.html >. Acess in: 03/07/2014.

PAULILLO, L. F. et al. Álcool combustível e biodiesel no Brasil. Revista de Economia e Sociologia Rural, v. 45, p. 531-565, 2007.

SCHWARZENBACH, R. P.; GSCHWEND, P. M.; IMBODEN, D. M. Environmental Organic Chemistry. John Wiley \& Sons, Inc., 2005.

SOUTHWORTH, G.R., The Role of Volatilization in Removing Polycyclic Aromatic Hydrocarbons from Aquatic Environments. Bull. Environ. Contam. Toxicol., 21 : 507-514, 1979.

TSUKUE, N. et al. Toxicological evaluation of diesel emissions on A549 cells. Toxicology in Vitro, Vol. 24, n. 2, p. 363-369, 2010. 